\title{
Does living near a constellation of petrochemical, steel, and other industries impair health?
}

\author{
R S Bhopal, S Moffatt, T Pless-Mulloli, P R Phillimore, C Foy, C E Dunn, J A Tate
}

\begin{abstract}
Objectives-To investigate concern that local industrial air pollution in Teesside, England, was causing poor health, several areas there were compared with parts of the City of Sunderland.

Methods-Populations in similar social and economic circumstances but varying in their proximity to major industries were compared. Study populations lived in $\mathbf{2 7}$ housing estates in Teesside and Sunderland, north east England, with some data from subsets of estates. The estates were aggregated into zones (designated as $A, B$, and $C$ in Teesside where $A$ is closest to and $C$ furthest from industry, and $S$ in Sunderland). Zone $S$ provided a reference area. The hypothesis was that a health gradient both within Teesside $(A>B>C)$ and between Teesside and Sunderland $(A B C>S)$ would indicate a possible health effect of local industrial air pollution. Data presented were: mortality (1981-91) from 27 housing estates; population self completion questionnaire survey data (1993, 9115 subjects) from 15 housing estates; and general practitioner (GP) consultation data (1989-94) from 2201 subjects in 12 Teesside estates.
\end{abstract}

Results-The populations in the four zones were comparable for indicators including smoking habits, residential histories, and unemployment. All cause and cause specific mortalities were high compared with England and Wales. Mortality in all Teesside zones (ABC) combined was mostly higher than in zone $S$. In people aged $0-64$, lung cancer and respiratory disease showed gradients with highest mortality in areas closest to industry $(A>B>C$ and $A B C>S)$. The association was clearest for lung cancer in women (0-64 years old, trend across zones ABC, $\mathbf{p}=0.07$, directly standardised rate ratio relative to zone $S$ was $169(95 \%$ confidence interval (95\% CI) 116-122)). There were no important, consistent gradients in the hypothesised direction between zones in consultation rates in general practice, and self reported respiratory and nonrespiratory health including asthma.

Conclusions-There was no clear evidence that living close to industry was associated with morbidity, including asthma, or for most measures of mortality. For lung cancer in women the gradients indicated a health effect of local industrial air pollution. In the age group 0-64 observed gradients in lung cancer in men and mortality from respiratory disease in men and women were consistent with the study hypothesis, although not significant. The reasons for the different patterns at different ages, and between men and women, remain a puzzle.

(Occup Environ Med 1998;55:812-822)

Keywords: industry and health; air pollution; epidemiology

Teesside in north east England is the location of one of western Europe's largest steel and petrochemical complexes. Among the many industries there are ICI and British Steel. There has been longstanding debate about the relative contribution of industrial pollution and poverty to the high levels of ill health in Teesside. ${ }^{1-5}$ Two earlier studies into the effects of smoking and industrial pollution on lung cancer and mortality from bronchitis implicated industrial air pollution as a contributor to the high rates of these diseases in Teesside. ${ }^{23}$

Local debate about poverty, industrial air pollution, and ill health was fuelled by research showing that populations living in some of the poorest areas in Teesside had unexpectedly high death rates compared with similar areas in Sunderland, a city $25 \mathrm{~km}$ to the north. ${ }^{4}$ Between 1975 and 1986 the standardised mortality ratio (SMR) in the Teesside area was 158 , compared with 133 in Sunderland areas. ${ }^{4}$ One explanation was that air pollution from industry on Teesside was exacerbating health problems. The public in Teesside perceive air pollution to be the top ranking environmental problem and identified industry as a major contributor. ${ }^{5}$ The public, health professionals, the media, and local statutory agencies have been embroiled in the health controversy, and when this study began litigation by residents against local industries was threatened.

This study tried to answer three questions:

- What is the health status of populations living in the poorest areas of Teesside?

- How does the health status of people in Teesside compare with those in Sunderland, and specifically, do morbidity patterns show the same disparity as those of mortality?

- Has air pollution from local industry impaired the health of people living close by?

Papers focusing on otitis media and lung cancer have been published. ${ }^{67}$ This paper gives an overview of the key finding of a complex report, ${ }^{8}$ develops some of the earlier analysis, and focuses on the third question above, presenting data from a community question- 


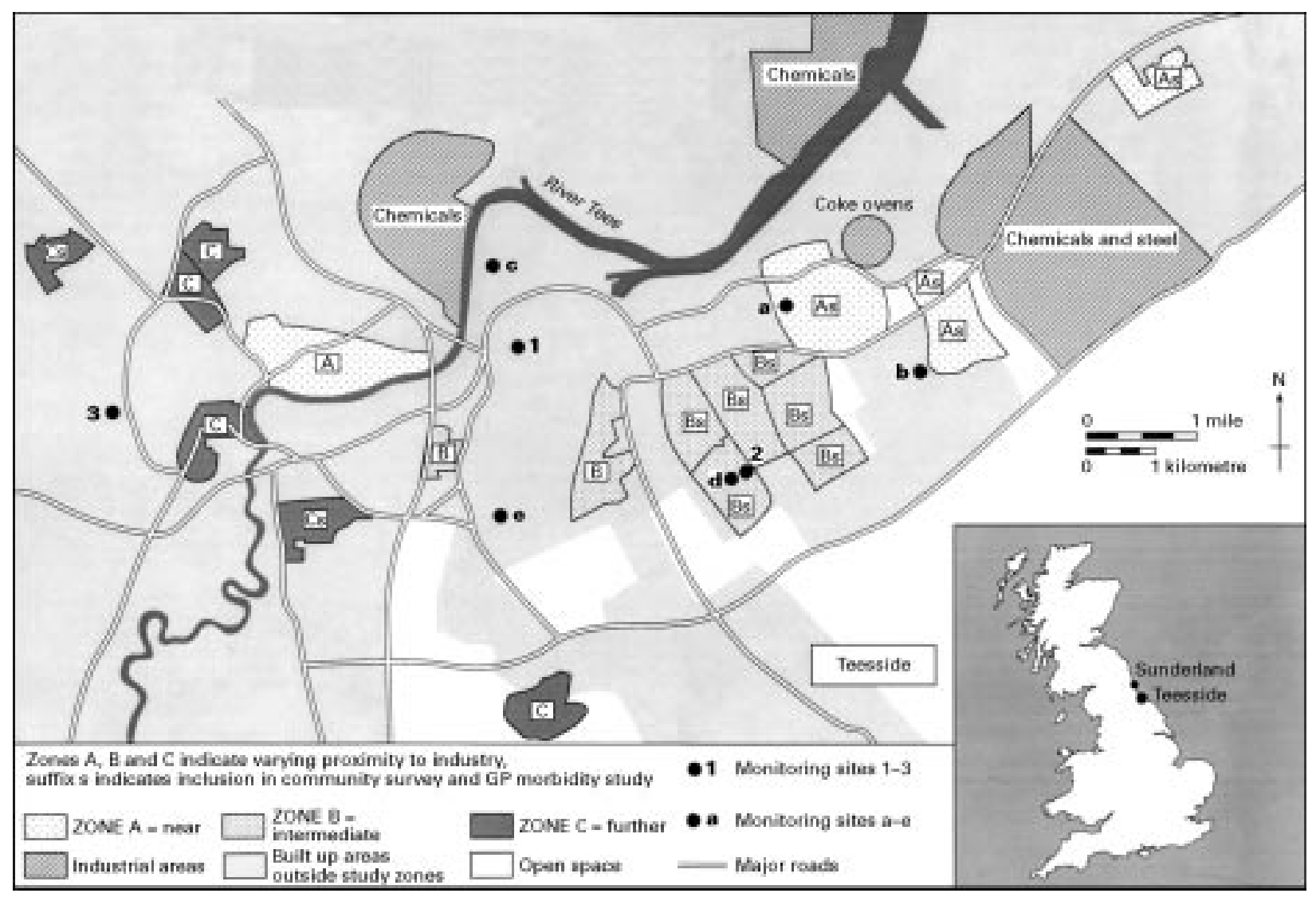

Housing estates chosen for the health study and location of selected monitoring sites for smoke and $\mathrm{SO}_{2}$ in Teesside

naire survey, an analysis of general practice records, and mortality statistics. Information on perinatal deaths, stillbirths, birthweights, otitis media based on a screening survey, ${ }^{6}$ cancer registration, and a detailed review of environmental information including a land use survey are in our report. ${ }^{8}$ Before describing the epidemiological studies we briefly summarise knowledge on air quality in Teesside, and introduce the study design and the terminology used for the areas under investigation.

STUDY DESIGN, AREAS STUDIED, AND OVERVIEW OF AIR POLLUTION IN THE TEESSIDE ENVIRONMENT

We used proximity to industry as a surrogate for long term exposure to air pollution from local industries. Twenty seven housing estates in Teesside and Sunderland, north east England, were the focus of the study, with more detailed information from subsets of these estates. The estates were aggregated into zones (designated as A, B, and C in Teesside where A is closest to industry and $\mathrm{C}$ the furthest, and $\mathrm{S}$ in Sunderland). Areas in zone A have been the centre of concern for many decades about the potential effect of air pollution on health. ${ }^{148}$ Our strategy was to study the geographical areas where concern has been greatest and not restrict ourselves to those areas for which environmental data were already available. The areas are shown on the map.

Existing data on monitoring air pollution together with computer dispersion modelling and a historic land use survey helped (a) to characterise the spatial and temporal trends in health related air pollutants, $(b)$ to inform us of the likely validity of the selection of study areas based on residential proximity to industry as a proxy for exposure, and (c) to examine associations between general practitioner (GP) consultation rates and daily measures of air quality. This section summarises a complex set of data, much of which is discussed in detail elsewhere. ${ }^{8}$

A review of routinely available air quality monitoring data from the mid-1950s to the present showed abundant data for Teesside (reflecting long standing concerns about air pollution there) presented in annual reports of medical officers of health, ${ }^{9}{ }^{10}$ local government reports on air quality, ${ }^{112}{ }^{12}$ specifically commissioned studies, and the national air quality archive. Data on air quality in the 1960s and 1970s in the study zones are either not available, or are incomplete. Information about air quality in zone A areas is, surprisingly, less comprehensive than other areas despite the long standing concerns there. The best continuous data are for smoke and $\mathrm{SO}_{2}$, available from the Internet since 1997 (http:// www.aeat.co.uk/netcen/aqarchive/nonauto/ smkjava1.html). When systematic local authority monitoring started in the early 1960 s, it concentrated on smoke (as an indicator for fine suspended particles), $\mathrm{SO}_{2}$, insoluble deposits, and ferric oxide identified as a marker for industrial activity (especially steel). We identified spatial variations in air quality in Teesside; but this was not feasible in Sunderland, where less monitoring has taken place. We could not follow spatial patterns in air quality over time 
Table 1 Annual mean of smoke* concentrations in Teesside and Sunderland 1963-75 $\left(\mu \mathrm{g} / \mathrm{m}^{3}\right)$ (data source: internet site given in text)

\begin{tabular}{|c|c|c|c|c|c|c|c|c|c|}
\hline \multirow[b]{2}{*}{ Site codet } & \multirow[b]{2}{*}{ Study area } & \multirow{2}{*}{$\begin{array}{l}\text { Study zone if } \\
\text { applicablet }\end{array}$} & \multicolumn{7}{|l|}{ Year } \\
\hline & & & 1963 & 1965 & 1967 & 1969 & 1971 & 1973 & 1975 \\
\hline 1 & Teesside & & 107 & 60 & 51 & 32 & 25 & 22 & 19 \\
\hline 2 & & B & 57 & 49 & 51 & 43 & 32 & 23 & 19 \\
\hline 3 & & & 95 & 79 & 60 & 53 & 35 & 23 & 18 \\
\hline S1 & Sunderland & & 144 & 126 & 116 & - & - & - & 59 \\
\hline
\end{tabular}

*Smoke was used as a measurement of fine suspended particulate matter $<15 \mu \mathrm{m}$ by examining blackness of filters.

†See map for monitoring positions of sites and study zone B.

because monitoring sites were regularly relocated. Many sites to monitor spatial variations in smoke and $\mathrm{SO}_{2}$ came into operation in the early 1970 s, by which time the levels of these pollutants were greatly reduced.

The overall trend towards falling pollution levels from 1960 onwards is shown in table 1 for four sites (three in Teesside, one in Sunderland) for which continuous smoke monitoring data are available. One site falls within our zone B. No such data are available for our zones A and $\mathrm{C}$ or our Sunderland zone. This table shows higher smoke levels in Sunderland, reflecting the later introduction there of domestic smoke control measures.

Local government used insoluble solids and ferric oxide as key indicators of industrial pollution..$^{9-11}$ Insoluble solids are particulates of all sizes excluding secondary salts. Monitoring in Teesside showed persistently higher pollution in areas close to industry. Indicative data are presented in table 2 , which covers 6 years in the 1960 s, and shows a sharp gradient between industrial, semi-industrial, and residential areas (based on groupings of monitoring sites made by local government). ${ }^{9}{ }^{10}$ Little decline in pollution over time is evident in these years. Table 3 summarises variations in smoke and $\mathrm{SO}_{2}$ at particular monitoring sites for winter and summer in $1968 .{ }^{11}$ The site which falls within our zone A (marked a on the map) has the highest levels of smoke and $\mathrm{SO}_{2}$. Two further sites (marked $\mathrm{b}$ and $\mathrm{c}$ on the map) lie close to industry but outside our study zones; levels are generally higher at these two sites

Table 2 Mean monthly deposits of insoluble solids (tonnes/square mile) across Teesside (data source, ${ }^{9}{ }^{10}$ )

\begin{tabular}{lrrrrrr}
\hline & \multicolumn{2}{l}{ Year } & & & & \\
\cline { 2 - 7 } & 1962 & 1963 & 1964 & 1965 & 1966 & 1967 \\
\hline Industrial areas & 22 & 20 & 18 & 20 & 25 & 21 \\
Semi-industrial areas & 11 & 11 & 9 & 12 & 12 & 10 \\
Residential areas & 6 & 6 & 6 & 7 & 7 & 7 \\
\hline
\end{tabular}

Table 3 Mean concentrations of smoke and $\mathrm{SO}_{2}$ in Teesside 1968 in summer and winter in $\mu \mathrm{g} / \mathrm{m}^{3}$ (data source (11) $^{11}$

\begin{tabular}{|c|c|c|c|c|c|}
\hline \multirow[b]{3}{*}{ Site code } & \multirow{3}{*}{$\begin{array}{l}\text { Study zone, if } \\
\text { applicablet }\end{array}$} & \multicolumn{2}{|l|}{ Smoke } & \multicolumn{2}{|l|}{$\mathrm{SO}_{2}$} \\
\hline & & \multicolumn{2}{|l|}{ Season } & \multicolumn{2}{|l|}{ Season } \\
\hline & & Winter & Summer & Winter & Summer \\
\hline $\mathrm{a}$ & A & 284 & 84 & 211 & 72 \\
\hline b & & 98 & 37 & 151 & 58 \\
\hline c & & 140 & 33 & 109 & 49 \\
\hline $\mathrm{d}$ & B & 56 & 57 & 94 & 57 \\
\hline e & & 56 & 32 & 64 & 45 \\
\hline
\end{tabular}

${ }^{\star}$ Smoke was used as a measurement of fine suspended particulate matter $<15 \mu \mathrm{m}$ by examining blackness of filters.

†See map for monitoring positions of sites and study zones A and B. than at the site in zone B (marked d on the map), whereas levels are lowest at site e, which lies outside our study zones and well away from industry.

The high readings recorded for the zone A site, in the area known as South Bank, situated close to steel, coking, and chemical operations, are repeatedly mentioned in local documentation including local government reports from the late 1960s to the early 1980s. Within the first months of this monitoring site being introduced in late 1967, daily winter smoke peaks of over $700 \mu \mathrm{g} / \mathrm{m}^{3}$ were reported there..$^{10}$ The local government report on pollution between 1964 and 1973 summarised the position thus: "In contrast to the general improvements in all four pollutants there remain particular sites where the pollution is becoming worse or where high levels of pollution are still being registered. South Bank is the area most severely affected".${ }^{13}$ Even in 1981 this site still had the highest levels of $\mathrm{SO}_{2}$ in Teesside. These findings support our general strategy of basing choice of areas on proximity to industry.

In the 1990s local air quality monitoring has focused on pollutants - such as nitrogen dioxide $\left(\mathrm{NO}_{2}\right)$, ozone $\left(\mathrm{O}_{3}\right)$, small particles $\left(\mathrm{PM}_{10}\right)$, volatile organic compounds (VOCs), and polycyclic aromatic hydrocarbons (PAHs) - few of which were monitored before 1989. The concentrations have mostly been below long term guideline values. Problems with short term and localised peaks were a continuing concern. ${ }^{814}$ Results of monitoring benzene from Middlesbrough, the largest town within Teesside, showed sporadic peaks of benzene superimposed on a steady baseline not found at other United Kingdom centres with automatic monitoring sites. Such peaks have been associated with industrial sources. ${ }^{14}$

Dispersion modelling of various pollutants in Teesside, which distinguished industrial from other kinds of emissions, suggested that spatial variations remain, although annual mean concentrations were low. ${ }^{8}$ Table 4 presents modelled $\mathrm{NO}_{\mathrm{x}}$ and benzene concentrations for 1993 and 1994. The $\mathrm{NO}_{\mathrm{x}}$ is used in this context to illustrate uneven overall pollution loads coupled with differentials in the relative contribution from industrial sources. Highest predicted concentrations were along busy roads and around housing areas closest to major industries. In some areas closest to industry the industrial contribution to both $\mathrm{NO}_{\mathrm{x}}(59 \%$ in 1994) and benzene $(78 \%$ in 1994) was well above the national average of $38 \%$ and $32 \%$ respectively, whereas modelled 
Table 4 Relative modelled contributions from industry to NOx and benzene emissions 1993-4 in selected areas

\begin{tabular}{lccc}
\hline Zone, pollutant & Year & $\begin{array}{l}\text { Total } \\
\text { concentration } \\
(p p b)\end{array}$ & $\begin{array}{l}\text { Industrial } \\
\text { contribution } \\
(\%)\end{array}$ \\
\hline Zone A: & & & \\
NOx & 1993 & 18.6 & 53.6 \\
NOx & 1994 & 15.6 & 59.0 \\
Benzene & 1993 & 0.77 & 74.7 \\
Benzene & 1994 & 0.59 & 78.2 \\
Zone B: & & & \\
NOx & 1993 & 20.6 & 22.2 \\
NOx & 1994 & 14.4 & 20.8 \\
Benzene & 1993 & 0.41 & 7.4 \\
Benzene & 1994 & 0.29 & 5.1 \\
Zone C: & & & \\
NOx & 1993 & 12.9 & 13.5 \\
NOx & 1994 & 9.4 & 14.2 \\
Benzene & 1993 & 0.27 & 8.0 \\
Benzene & 1994 & 0.21 & 6.6 \\
\hline
\end{tabular}

means for areas further away were well below these values. $^{814}$

A land use survey based on historical maps and archive data confirmed that those housing areas which are currently closest to industry were also close to industry throughout most of this century. ${ }^{8}$ Specifically, industry has been close to zone A throughout the century.

Overall, these data supported our assumption that residential proximity of a population to industry was a reasonable surrogate for long term exposure to local industrial emissions.

\section{Methods}

CHOICE OF AREAS

Areas close to Teesside's major industries are among the poorest neighbourhoods in the United Kingdom. The focus of this study was on the poorest parts of localities close to ICI and British Steel, previously identified as having exceptionally high mortalities, ${ }^{4}$ and socioeconomically comparable areas in Sunderland which served as a reference zone for this analysis. The poorest enumeration districts (EDs) in Teesside were identified with the Townsend deprivation index. ${ }^{4}$ Clusters of adjacent EDs with similar characteristics were aggregated and checked by fieldwork and local consultation as socially homogenous and locally recognisable neighbourhoods.

We sought populations at varying distances from industry, yet comparable on factors posing a risk to health such as smoking, occupation, and socioeconomic status. This study started before publication of the 1991 census, so 1981 census data were assembled for enumeration districts (EDs), the smallest unit area for which census data are available, consisting of a mean of about 150 households. When published, 1991 census data were examined to verify that study areas remained similar to one another in social characteristics. Twenty seven areas, 19 in Teesside (1991 population 77 330) and eight in Sunderland (population 43 485) were included.

As shown on the map, estates were grouped by distance from industry into those relatively near to (referred to as zone A), intermediate to (zone B), and further from industry (zone C). Sunderland estates, which are not shown on the map, formed a fourth zone (S). Studies were carried out at various levels of geographi- cal aggregation. Studies of routinely collected data covered all 27 estates; these data were also analysed for the subset of 15 estates (12 in Teesside, as shown on the map, and three in Sunderland) which correspond to the community survey. ${ }^{8}$ Other studies, requiring original data collection (community survey, GP morbidity study), concentrated on subsets of these 27 estates. In the map the 12 Teesside estates in which the community survey was carried out are identified by the letter "s" of the surveyAs, Bs, and Cs.

TEST OF THE STUDY HYPOTHESIS

This design permitted identification of gradients of ill health across zones. A prerequisite for us to consider data to support the study hypothesis that local industrial air pollution has an effect of on health was both a gradient across Teesside (highest rates in zone A, lowest in zone $\mathrm{C}$ ), and higher rates in the combined Teesside zones (ABC) than in Sunderland.

\section{Community survey}

A postal questionnaire, based mainly on previously tested questions, ${ }^{15}$ was sent to residents in 12 estates in Teesside (as shown on the map as zones As, Bs, and Cs) and the three estates in Sunderland (not shown on map). Questions covered socioeconomic circumstances, personal behaviour, illnesses, symptoms (focusing particularly on respiratory ill health), health status, and factors influencing health. The questionnaire is available from us and is reported in full elsewhere. ${ }^{8}$

Questionnaires were sent to 7524 Teesside adults; 2269 Sunderland adults; 3366 Teesside parents to complete on behalf of their children; and 1687 Sunderland parents. An overall response rate of $59.7 \%$ (9097 completed questionnaires) was achieved after two reminders. The response varied little among the Teesside zones, but was slightly lower in Sunderlandfor example, for adults it was $59.8 \%$ compared with $62.3 \%$ in Teesside. Odds ratios and their $95 \%$ confidence intervals (95\% CIs) for self reported illnesses and symptoms were calculated with multiple logistic regression, with zone $S$ as the reference population. Logistic regression was also used to test the hypothesis that a trend in odds ratios would be found (zone $\mathrm{A}>$ zone $\mathrm{B}>$ zone $\mathrm{C}$ ).

General practice records

For pragmatic reasons of time and cost this part of the study was carried out in Teesside only, in nine GPs' practices, three in each of zones A, B, and C. A sub-sample of people from the community survey was selected with a systematic sampling technique. From each practice 240 adults and children were selected giving a sample size of 720 in each of the three zones.

Customised encoding software developed to our specification by the company Computer Aided Medical Systems (Loughborough, UK) was used to extract date of consultation, diagnosis or symptoms, repeat prescriptions, chronic illnesses, and hospital in-patient 
Table 5 Socioeconomic circumstances, housing conditions, smoking, and occupational experience by area

\begin{tabular}{|c|c|c|c|c|}
\hline & $\begin{array}{l}\text { Zone A } \\
(n=1539)\end{array}$ & $\begin{array}{l}\text { Zone B } \\
(n=1464)\end{array}$ & $\begin{array}{l}\text { Zone C } \\
(n=1486)\end{array}$ & $\begin{array}{l}\text { Zone S } \\
(n=1910)\end{array}$ \\
\hline Adults (16-79y) & $\%$ & $\%$ & $\%$ & $\%$ \\
\hline \multicolumn{5}{|c|}{ Indicators of socioeconomic circumstances: } \\
\hline No access to car or van & 45 & 53 & 51 & 57 \\
\hline Rented housing & 52 & 59 & 63 & 72 \\
\hline Male unemployment & 30 & 32 & 33 & 35 \\
\hline Female unemployment & 12 & 15 & 14 & 16 \\
\hline Overcrowded households ${ }^{\star}$ & 6 & 5 & 5 & 4 \\
\hline Left school 16 years or under & 93 & 94 & 94 & 94 \\
\hline \multicolumn{5}{|l|}{ Residential history: } \\
\hline Mean years at current address ( $n$ ) & 14 & 18 & 17 & 17 \\
\hline Same address for most of life & 57 & 58 & 59 & 51 \\
\hline \multicolumn{5}{|l|}{ Housing conditions: } \\
\hline Damp in house & 21 & 17 & 17 & 22 \\
\hline \multicolumn{5}{|l|}{ Heating and cooking: } \\
\hline Coal fires & 1 & 1 & 1 & 6 \\
\hline Gas fires & 41 & 39 & 47 & 50 \\
\hline Gas cooker & 72 & 69 & 74 & 72 \\
\hline \multicolumn{5}{|l|}{ Smoking habits: } \\
\hline \multicolumn{5}{|l|}{ Men: } \\
\hline Never smoked & 26 & 26 & 27 & 24 \\
\hline Ex-smokers & 37 & 35 & 39 & 40 \\
\hline Current smokers & 37 & 39 & 35 & 36 \\
\hline \multicolumn{5}{|l|}{ Women: } \\
\hline Never smoked & 35 & 33 & 31 & 36 \\
\hline Ex-smokers & 24 & 24 & 24 & 26 \\
\hline Current smokers & 40 & 43 & 45 & 38 \\
\hline Number of alcohol units/week & 11 & 12 & 11 & 11 \\
\hline Never or hardly ever take exercise & 58 & 59 & 63 & 63 \\
\hline \multicolumn{5}{|l|}{ Occupational history: } \\
\hline \multicolumn{5}{|c|}{ Worked in one of the industries for $>1 \mathrm{y}: \dagger$} \\
\hline Men & 59 & 48 & 43 & 42 \\
\hline Women & 10 & 9 & 10 & 10 \\
\hline \multicolumn{5}{|c|}{ Worked in dusty industry for most of working life: } \\
\hline Men & 31 & 28 & 23 & 33 \\
\hline Women & 7 & 8 & 7 & 9 \\
\hline
\end{tabular}

$\star>1$ Person/room

†Industries: car industry, chemical industry, coal mining, coke works, gas works, industrial maintenance, iron or steel works, oil or gas drilling, petroleum and oil refining, plastics and lamination factory, shipyard or ship repair, tar distillery.

episodes from patient records for the period December 1989 to September 1994.

Environmental data corresponding with some of the period of GP data were available for two sites. Hourly readings of $\mathrm{NO}_{2}$ and $\mathrm{SO}_{2}$ were available from a site close to zone $\mathrm{A}$, from January 1992 until September 1994, albeit with some gaps. These were used in conjunction with the general practice data from zone A. Hourly readings of particulates $\left(\mathrm{PM}_{10}\right), \mathrm{NO}_{2}$, $\mathrm{SO}_{2}$, and $\mathrm{O}_{3}$ were available from a site in zone B for June 1993 to September 1994; these were used with the data from general practices in zone B. For analysis we used the mean over each period 0900 to 0800 the next day, and the maximum reading in the period.

To assess whether the consultation rate varied significantly with air quality, a Poisson $\log$ linear model of the number of daily consultations was used, taking into account day of the week, daily temperature (average of the minimum and maximum temperatures in the previous 24 hours) and mean and peak daily pollutant values up to 0800 that day. This model was implemented with the statistical package GLIM. Consultations were also analysed for air quality during the 24 hours up to 0800 on the previous day.

Table 6 Adjusted ${ }^{\star}$ odds ratios (95\% CIs) of self reported illness and symptoms with Sunderland as the reference population

\begin{tabular}{|c|c|c|c|c|c|}
\hline Adults & $\begin{array}{l}\text { Zone } A(n=1539) \text { OR } \\
(95 \% C I)\end{array}$ & $\begin{array}{l}\text { Zone B }(n=1464) \text { OR } \\
(95 \% \text { CI })\end{array}$ & $\begin{array}{l}\text { Zone } C(n=1486) \text { OR } \\
(95 \% C I)\end{array}$ & $\begin{array}{l}\text { Zone A to } B \text { to } C \\
\text { trend } \chi^{2}(2 d f) P \text { value }\end{array}$ & $\begin{array}{l}A B C v S+O R \\
(95 \% C I)\end{array}$ \\
\hline Long term limiting illness & $0.95(0.80$ to 1.12$)$ & $0.86(0.73$ to 1.02$)$ & $0.83(0.70$ to 0.98$)$ & 0.32 & $0.88(0.77$ to 1.01$)$ \\
\hline \multicolumn{6}{|l|}{ Illnessł: } \\
\hline Chronic bronchitis & $1.23(0.93$ to 1.63$)$ & $1.46(1.11$ to 1.93$)$ & $1.19(0.89$ to 1.59$)$ & 0.18 & $1.29(1.03$ to 1.63$)$ \\
\hline Hay fever & $1.12(0.84$ to 1.49$)$ & $1.25(0.94$ to 1.66$)$ & $1.15(0.86$ to 1.54$)$ & 0.84 & $1.17(0.93$ to 1.48$)$ \\
\hline Sinus trouble & $1.06(0.84$ to 1.33$)$ & $1.20(0.96$ to 1.51$)$ & $1.07(0.84$ to 1.35$)$ & 0.46 & $1.10(0.92$ to 1.33$)$ \\
\hline Tuberculosis & 0.57 ( 0.33 to 0.99$)$ & $0.91(0.56$ to 1.48$)$ & $0.72(0.43$ to 1.21$)$ & 0.23 & 0.73 (0.49 to 1.08$)$ \\
\hline \multicolumn{6}{|l|}{ Symptoms in previous month: } \\
\hline Colds or flu & $0.91(0.78$ to 1.06$)$ & $0.86(0.74$ to 1.00$)$ & $0.90(0.78$ to 1.05$)$ & 0.68 & $0.89(0.79$ to 1.00$)$ \\
\hline Sinus or catarrh & $0.87(0.70$ to 1.09$)$ & $0.97(0.78$ to 1.21$)$ & $0.98(0.79$ to 1.22$)$ & 0.60 & $0.95(0.80$ to 1.12$)$ \\
\hline Skin rash or trouble & $0.97(0.79$ to 1.20$)$ & $0.97(0.80$ to 1.20$)$ & $1.04(0.84$ to 1.29$)$ & 0.85 & $0.99(0.84$ to 1.17$)$ \\
\hline Ever had asthma & $0.79(0.61$ to 1.02$)$ & $0.98(0.77$ to 1.26$)$ & $1.07(0.84$ to 1.36$)$ & 0.28 & $0.94(0.78$ to 1.14$)$ \\
\hline Those with asthma only (n) & 203 & 213 & 215 & & \\
\hline \multicolumn{6}{|l|}{ In previous year: } \\
\hline 4-12 Asthma attacks & $0.70(0.50$ to 0.98$)$ & $0.86(0.62$ to 1.19$)$ & $0.88(0.63$ to 1.22$)$ & & $0.81 \S(0.63$ to 1.04$)$ \\
\hline$>12$ Asthma attacks & $1.28(0.89$ to 1.85$)$ & $1.04(0.72$ to 1.52$)$ & $0.83(0.56$ to 1.24$)$ & $0.20 \rrbracket$ & $1.05(0.78$ to 1.42$)$ \\
\hline
\end{tabular}

${ }^{\star}$ Odds ratio adjusted for: age, sex, smoking, alcohol consumption, exercise level, occupation in heavy industry, damp housing, coal fires, and gas appliances. †Zone CS $(\mathrm{n}=1910)$.

$\ddagger$ Responses to survey question to "Have you ever had, or been told you have any of the following illnesses".

\Zone CS $(\mathrm{n}=278)$.

ฯ4 df. 
Table 7 Adjusted ${ }^{\star}$ odds ratios of self reported illness and symptoms with Sunderland as the reference population

\begin{tabular}{|c|c|c|c|c|c|}
\hline Children & $\begin{array}{l}\text { Zone A }(n=641) \text { OR } \\
(95 \% C I)\end{array}$ & $\begin{array}{l}\text { Zone B }(n=614) \text { OR } \\
(95 \% \text { CI })\end{array}$ & $\begin{array}{l}\text { Zone } C(n=633) \text { OR } \\
(95 \% C I)\end{array}$ & $\begin{array}{l}\text { Zone } A, B, C \text { trend } \\
x^{2} n(2 d f) P \text { value }\end{array}$ & $\begin{array}{l}A B C v S+O R \\
(95 \% C I)\end{array}$ \\
\hline Long term limiting illness & $1.07(0.76$ to 1.52$)$ & $1.03(0.73$ to 1.46$)$ & $1.05(0.74$ to 1.48$)$ & 0.70 & $1.05(0.80$ to 1.39$)$ \\
\hline \multicolumn{6}{|l|}{ Illness $\ddagger:$} \\
\hline Bronchitis & $1.20(0.75$ to 1.92$)$ & $1.92(1.26$ to 2.95$)$ & $1.88(1.23$ to 2.87$)$ & 0.14 & $1.66(1.16$ to 2.40$)$ \\
\hline Glue ear & $1.42(0.96$ to 2.10$)$ & $1.41(0.95$ to 2.09$)$ & $1.50(1.02$ to 2.20$)$ & 0.96 & $1.44(1.05$ to 1.99$)$ \\
\hline Hay fever & $1.07(0.66$ to 1.74$)$ & $1.21(0.76$ to 1.95$)$ & $0.97(0.59$ to 1.59$)$ & 0.88 & $1.08(0.74$ to 1.59$)$ \\
\hline Sinus trouble & $1.31(0.78$ to 2.20$)$ & $0.97(0.56$ to 1.69$)$ & $0.83(0.47$ to 1.47$)$ & 0.16 & $1.03(0.67$ to 1.39$)$ \\
\hline Itchy rash or eczema & $1.38(1.04$ to 1.83$)$ & $1.12(0.84$ to 1.49$)$ & $1.59(1.21$ to 2.08$)$ & 0.05 & $1.36(1.08$ to 1.70$)$ \\
\hline \multicolumn{6}{|l|}{ Symptoms in previous month: } \\
\hline Colds or flu & $1.22(0.97$ to 1.55$)$ & 0.85 (0.68 to 1.08$)$ & $1.12(0.89$ to 1.41$)$ & 0.02 & $1.05(0.88$ to 1.26$)$ \\
\hline Sinus or catarrh & $1.23(0.78$ to 1.95$)$ & $1.05(0.65$ to 1.68$)$ & $1.05(0.66$ to 1.66$)$ & 0.59 & $1.03(0.72$ to 1.48$)$ \\
\hline Skin rash or trouble & $1.26(0.90$ to 1.76$)$ & $0.99(0.70$ to 1.40$)$ & $1.40(1.02$ to 1.93$)$ & 0.05 & $1.21(0.93$ to 1.59$)$ \\
\hline Ever had asthma & $0.84(0.61$ to 1.15$)$ & $0.76(0.55$ to 1.04$)$ & $1.02(0.76$ to 1.36$)$ & 0.13 & $0.87(0.69$ to 1.11$)$ \\
\hline Those with asthma only (n) & 108 & 92 & 107 & & \\
\hline \multicolumn{6}{|l|}{ In previous year: } \\
\hline 4-12 Asthma attacks & $0.73(0.43$ to 1.26$)$ & $0.65(0.37$ to 1.13$)$ & $1.15(0.70$ to 1.89$)$ & & $0.85 \$(0.56$ to 1.28$)$ \\
\hline$>12$ Asthma attacks & $2.01(0.90$ to 4.50$)$ & $1.83(0.80$ to 4.16$)$ & $0.55(0.20$ to 1.53$)$ & 0.0 雨 & $1.38(0.68$ to 2.78$)$ \\
\hline
\end{tabular}

$\star^{\star}$ Odds ratios adjusted for: damp housing to overcrowding to parental smoking to family history of asthma to gas appliances and coal fires

†Zone CS to $\mathrm{N}=828$

$\ddagger$ Responses to survey question, "Has your child had to or have you been told they have any of the following illnesses".

¿Zone CS $(\mathrm{n}=189)$.

ฯ4 df.

Mortality data

Postcoded data on mortality were obtained from the former Northern Regional Health Authority. Individual postcodes were allocated to 1981 Census enumeration district codes with Newcastle University's POSTCODERX programme. ${ }^{8}$ Comparing some of the Northern Regional Health Authority data with the Office for National Statistics published data showed inconsequential discrepancies. ${ }^{8}$

Deaths of permanent residents of institutions were excluded. ${ }^{16} \mathrm{~A}$ mid-decade denominator was constructed with census data for the populations resident in private households (1981) and resident in households (1991) to match the numerator of non-institutional deaths. Underenumeration of the population in the 1991 census in our 27 areas of study was minimal-for example, zone A $1.4 \%$, zone B $0.7 \%$, zone C $1.4 \%$, and zone S $0.8 \% .{ }^{17}$

Mortality data were analysed at various levels: by the 27 housing estates individually; by the 15 estates selected for the community survey grouped into three Teesside zones and one in Sunderland; and by 27 estates grouped into three Teesside zones and one Sunderland zone. Mortality data were subject to two further levels of analysis. The three Teesside zones were subdivided into five. Differences over time were sought by analysing data from 1981-4, 1985-7, and 1988-91 separately. The full analysis is in our report. ${ }^{8}$ In this paper the focus is on the 27 estates grouped into four zones.

Age and sex stratified rates were examined for key analyses. Our emphasis on the 0-64 year age group (as well as all ages) was to allow comparability with earlier work by Phillimore and Morris, ${ }^{4}$ and to act on the finding that inequalities in health tend to diminish in elderly people and are sharpest in young and middle aged people. Then, both direct and indirect standardised rates were calculated and found to be similar. ${ }^{8}$ In this paper (unlike the report) the mortality data are primarily summarised as directly standardised rate ratios (DSRRs) with the mortalities for Sunderland as the reference population. (Analyses based on SMRs with England and Wales as the standard are in our report. ${ }^{8}$ )
The DSRRs (95\% CIs) were calculated for each of zones A, B, and C separately, and for Teesside as a whole, in each case with Sunderland as the reference population. The hypothesis of a trend in mortality within Teesside $(A>B>C)$ was tested with logistic regression for a trend in the probability of dying from 1981 to 1991 in zones A, B, C, taking into account sex and 5 year age group.

\section{Results}

INDICATORS OF SOCIOECONOMIC AND LIFESTYLE COMPARABILITY OF POPULATIONS

Table 5 contains socioeconomic and lifestyle indicators for adults from the community survey and shows that the populations were broadly comparable. This was not a surprise as census data on socioeconomic factors formed the basis for choosing study areas. ${ }^{8}$ Levels of male and female unemployment were similar as were educational levels. Population stability was also similar although fewer Sunderland residents $(51 \%)$ had stayed at the same address for most of their life than had Teesside residents (58\%). Damp housing affected slightly more Sunderland than Teesside residents and within Teesside affected more people in zone A than the other zones. Gas fired heating was slightly more common in zone $\mathrm{C}$ than in A and B. More homes in Sunderland were heated by coal fires or gas fires when compared with Teesside. Smoking patterns, alcohol consumption, and exercise showed small differences. The findings for the children's sample were similar ${ }^{8}$ (data available on request from authors). These data bolstered the assumption based on 1981 and 1991 census data, that on lifestyle as well as socioeconomic grounds, the respondents from the four zones were comparable populations. ${ }^{8}$

Occupational details are summarised in table 5. Among women, no differences were apparent. For men, sizeable differences did exist, with populations in zone A having the highest prevalence of men working in one of 12 major industries, and within Teesside, in working in a dusty industry. 
Table 8 Reasons for consultation by area

\begin{tabular}{lllll}
\hline Consultations/patient-year & Zone A & Zone B & Zone C & Total \\
\hline Patients (n) & 734 & 724 & 743 & 2201 \\
Total consultations & 3.97 & 4.45 & 3.86 & 4.09 \\
Respiratory diagnosis & 0.71 & 0.68 & 0.68 & 0.69 \\
Coughs reported & 0.32 & 0.58 & 0.25 & 0.38 \\
Asthma diagnosis & 0.04 & 0.05 & 0.06 & 0.05 \\
Bronchitis diagnosis & 0.05 & 0.12 & 0.18 & 0.12 \\
Upper respiratory tract infection diagnosed & 0.58 & 0.51 & 0.48 & 0.53 \\
\hline
\end{tabular}

SELF REPORTED HEALTH

Data on a wide range of chronic health problems, illnesses, and symptoms were collected. ${ }^{8}$ We focus here on respiratory ill health. The main findings for adults and children are presented in tables 6 and 7 respectively. In adults, there were no clear cut gradients in the hypothesised directions in respiratory morbidity within Teesside, although Teesside had a higher prevalence of chronic bronchitis, hay fever, and sinusitis than Sunderland. Among people with asthma in Teesside, a higher proportion of those living in zone A experienced $>12$ attacks in the year before the survey but this pattern was not mirrored for 4-12 asthma attacks, and differences between Teesside and Sunderland were small. The ill health experience across the four zones was similar for a wider range of non-respiratory problems as reported elsewhere. ${ }^{8}$

Among children (table 7) there were some differences across the Teesside areas but there were no clear gradients in the hypothesised direction. Although sinus trouble showed a gradient $(\mathrm{A}>\mathrm{B}>\mathrm{C})$ across Teesside the prevalence in Teesside was almost identical to zone $\mathrm{S}$. With the exception of asthma, all illnesses listed were higher within Teesside as a whole than within Sunderland. As with adults, there was evidence suggestive that a higher proportion of those living in zone A had $>12$ asthma attacks, but no similar pattern occurred for 4-12 attacks.

GENERAL PRACTICE DATA

Table 8 shows that consultation rates were higher in zone B than in zone A and lowest in zone C. Respiratory diagnoses disaggregated into different categories showed marginal differences and no pattern across the areas. Furthermore, the three zone A practices combined had lower hospital admission rates, chronic conditions, and repeat prescription

Table 9 Zone A consultation rates by daily peak $\mathrm{NO}_{2}$ and $\mathrm{SO}_{2}$ concentrations

\begin{tabular}{llll}
\hline & & $\begin{array}{l}\text { Total } \\
\text { consultations / } \\
\text { patient-year }\end{array}$ & $\begin{array}{l}\text { Respiratory } \\
\text { consultations } / \\
\text { patient-year }\end{array}$ \\
\hline $\mathrm{NO}_{2}$ category: & Days (n) & & \\
$\mathrm{Up}$ to $23 \mathrm{ppb}$ & 418 & 4.05 & 0.71 \\
24 to $38 \mathrm{ppb}$ & 321 & 4.26 & 0.82 \\
$39 \mathrm{ppb}$ or more & 75 & 4.27 & 0.68 \\
Total & 814 & 4.15 & 0.75 \\
$\chi^{2}$ for effect of $\mathrm{NO}_{2}$ (to 0800 same day) & & $0.11, \mathrm{p}=0.74$ & $1.45, \mathrm{p}=0.23$ \\
$\chi^{2}$ for effect of $\mathrm{NO}_{2}$ (to 0800 previous day) & & $0.04, \mathrm{p}=0.84$ & $0.39, \mathrm{p}=0.53$ \\
$\mathrm{SO}_{2}$ category: & 259 & 4.26 & 0.84 \\
Up to 8 ppb & 190 & 4.06 & 0.77 \\
9 to 38 ppb & 48 & 4.58 & 0.73 \\
39 ppb or more & 497 & 4.22 & 0.80 \\
Total & & $0.37, \mathrm{p}=0.54$ & $3.09, \mathrm{p}=0.08$ \\
$\chi^{2}$ for effect of $\mathrm{SO}_{2}$ (to 0800 same day) & $5.00, \mathrm{p}<0.03$ & $3.45, \mathrm{p}=0.06$ \\
$\chi^{2}$ for effect of $\mathrm{SO}_{2}$ (to 0800 previous day) & & & \\
\hline
\end{tabular}

items dispensed than did practices in the other two areas (data not shown here). ${ }^{8}$

Table 9 shows the association between consultation rates and daily peak $\mathrm{NO}_{2}$ and $\mathrm{SO}_{2}$ concentrations in zone A. Slight increases in consultation rates on days when pollutants were higher were found, but the associations were not significant with one exception: overall consultations were raised on days when the $\mathrm{SO}_{2}$ concentration up to 0800 the previous day was relatively high.

\section{MORTALITY}

Table 10 shows that at all ages, all cause mortality showed a slight Teesside gradient $(\mathrm{A}>\mathrm{B}>\mathrm{C}$; NS) among men but not among women. Mortality ratios for all Teesside zones (ABC) combined were marginally higher than zone $S(A B C>S)$ for men but not for women. All cause mortality for the 0-64 age group exhibited a gradient among men $(p=0.11)$ and women $(p=0.16)$ and was higher for all Teesside zones, compared with zone $S$, in both men and women.

Mortality for all cancers excluding lung cancer, showed no gradients in the hypothesised direction across the Teesside zones but mortality ratios were generally higher for all Teesside zones combined than for zone S.

For some analyses specific to cancer site, the number of cases were too small for meaningful comparisons, and for some others which are presented (digestive system, lymphatic or haematopoietic, bladder, genitourinary, lip or oral cavity) only all age analyses were possible. For most of the analyses specific to cancer site there were no gradients in the hypothesised direction across the Teesside zones. With the exception of breast cancer in women of all ages, however, the three Teesside zones combined had higher (or equal) cancer rates than zone $S$. Across the Teesside zones a gradient in the hypothesised direction for lung cancer was not present in men of all ages, and unclear for women at all ages (but the gradient is significant, in fact, zone $\mathrm{C}$ has a higher ratio than zone $\mathrm{B}$ ). The hypothesised gradient was present for men and women aged $0-64(p=0.69$ for men, 0.07 for women). For women aged 0-64 in zone A, the DSRR was 229, this being standardised to zone S, an area which itself has a high SMR for lung cancer (SMR 170). ${ }^{78}$ The SMR for lung cancer in women aged $0-64$ in zone A, standardised to England and Wales mortality data, was 387 (95\% CIs 277-525). ${ }^{78}$ The mortality ratio for lung cancer in the three Teesside zones was substantially higher than zone $S$ in women of all ages, and particularly, 0-64 years. For a fuller analysis based on SMRs see reference $8 .{ }^{8}$

There was no clear gradient in respiratory mortality in men of all ages across Teesside zones. Such gradients were there for women of all ages $(p=0.29)$ and for men $(p=0.33)$ and women aged $0-64(p=0.07)$. For all the age groups, respiratory mortality ratios were higher for Teesside zones combined than for zone $\mathrm{S}$ (95\% CIs included 100). For chronic obstructive airways disease there were no gradients in the hypothesised direction across the Teesside 
Table 10 Directly standardised rate ratios (DSRRs), 95\% CIs, and number of deaths 1981-91, standardised to Sunderland population (DSRR=100)

\begin{tabular}{|c|c|c|c|c|c|c|c|c|c|c|c|c|c|}
\hline & \multicolumn{3}{|l|}{ Zone $A$} & \multicolumn{3}{|l|}{ Zone B } & \multicolumn{3}{|l|}{ Zone $C$} & \multicolumn{2}{|c|}{ Tees trend ${ }^{\star}$} & \multicolumn{2}{|c|}{$A B C$ vs $S$} \\
\hline & DSRR & $(95 \% C I)$ & $n$ & DSRR & $(95 \% C I)$ & $n$ & $\overline{D S R R}$ & $(95 \% C I)$ & $n$ & $x^{2}$ & $p$ Value & DSRR & $(95 \% C I)$ \\
\hline \multicolumn{14}{|l|}{ All cause mortality: } \\
\hline Men, all ages & 107 & (100 to 114$)$ & 1276 & 103 & (97 to 108 ) & 2458 & 102 & (96 to 109 ) & 1329 & 1.10 & 0.29 & 104 & (99 to 108$)$ \\
\hline Women, all ages & 106 & (98 to 114 ) & 1029 & 95 & (90 to 101 ) & 1981 & 97 & (90 to 104 ) & 1111 & 4.07 & 0.04 & 98 & (94 to 103 ) \\
\hline Men, 0 to 64 & 115 & (103 to 127$)$ & 522 & 109 & (100 to 118$)$ & 1049 & 105 & (95 to 116$)$ & 530 & 2.45 & 0.11 & 110 & (102 to 117$)$ \\
\hline Women, 0 to 64 & 130 & (112 to 147$)$ & 302 & 123 & (109 to 136$)$ & 644 & 115 & (99 to 131 ) & 297 & 1.96 & 0.16 & 122 & (111 to 134$)$ \\
\hline \multicolumn{14}{|c|}{ All cancers excluding lung: } \\
\hline Men, all ages & 103 & (86 to 120$)$ & 196 & 109 & (95 to 123 ) & 418 & 112 & (95 to 130 ) & 227 & 0.58 & 0.45 & 108 & (96 to 120 ) \\
\hline Women, all ages & 98 & (81 to 115$)$ & 176 & 112 & (98 to 126$)$ & 438 & 106 & (89 to 123 ) & 220 & 0.55 & 0.46 & 108 & (98 to 119 ) \\
\hline Men, 0 to 64 & 104 & (77 to 131$)$ & 80 & 109 & ( 88 to 131 ) & 181 & 115 & ( 87 to 143 ) & 96 & 0.32 & 0.57 & 110 & (91 to 128$)$ \\
\hline Women, 0 to 64 & 124 & (89 to 158$)$ & 71 & 147 & (117 to 177 ) & 194 & 136 & (101 to 172 ) & 86 & 0.32 & 0.57 & 138 & (113 to 164$)$ \\
\hline \multicolumn{14}{|l|}{ Site specific cancers: } \\
\hline \multicolumn{14}{|c|}{ Digestive system cancers: } \\
\hline Men, all ages & 94 & (71 to 118$)$ & 86 & 115 & (94 to 136 ) & 213 & 125 & (98 to 153 ) & 120 & 3.48 & 0.06 & 112 & (94 to 130$)$ \\
\hline Women, all ages & 80 & (55 to 104 ) & 51 & 129 & (102 to 156$)$ & 176 & 94 & (68 to 120 ) & 71 & 0.52 & 0.47 & 109 & (89 to 129$)$ \\
\hline \multicolumn{14}{|c|}{ Lymphatic haematopoietic: } \\
\hline Men, all ages & 96 & (36 to 156 ) & 14 & 116 & ( 61 to 171 ) & 32 & 114 & (48 to 179 ) & 17 & 0.08 & 0.78 & 110 & (65 to 155$)$ \\
\hline Women, all ages & 112 & (42 to 182 ) & 14 & 98 & (48 to 148 ) & 26 & 159 & (73 to 244 ) & 22 & 0.98 & 0.32 & 117 & (68 to 166$)$ \\
\hline \multicolumn{14}{|l|}{ Bladder cancer: } \\
\hline Men, all ages & 143 & (56 to 229 ) & 16 & 132 & ( 66 to 199 ) & 31 & 159 & ( 67 to 250 ) & 19 & 0.13 & 0.72 & 141 & (80 to 201 ) \\
\hline Women, all ages & 66 & $(-16$ to 148$)$ & 3 & 121 & (30 to 212 ) & 13 & 143 & (18 to 267 ) & 8 & 1.58 & 0.21 & 115 & (39 to 191 ) \\
\hline \multicolumn{14}{|c|}{ Genitourinary cancers: } \\
\hline Men, all ages & 93 & (54 to 132$)$ & 30 & 107 & (73 to 140 ) & 69 & 114 & (71 to 157$)$ & 39 & 0.63 & 0.43 & 105 & (76 to 133 ) \\
\hline Women, all ages & 85 & (27 to 142$)$ & 11 & 107 & (54 to 159 ) & 29 & 99 & (40 to 158 ) & 16 & 0.34 & 0.56 & 100 & (58 to 143 ) \\
\hline \multicolumn{14}{|c|}{ Lip/oral cavity cancer: } \\
\hline Men, all ages & 102 & (13 to 190$)$ & 7 & 103 & (33 to 174 ) & 15 & 90 & (12 to 169 ) & 7 & 0.03 & 0.86 & 100 & (42 to 158 ) \\
\hline Women, all ages & 97 & $(-58$ to 251$)$ & 2 & 192 & $(-7$ to 390$)$ & 9 & 46 & $(-51$ to 144$)$ & 1 & 0.35 & 0.56 & 131 & ( 3 to 260 ) \\
\hline \multicolumn{14}{|l|}{ Breast cancer: } \\
\hline Women, all ages & 121 & (76 to 166$)$ & 40 & 79 & (53 to 105 ) & 52 & 103 & (64 to 142 ) & 38 & 0.55 & 0.46 & 95 & (70 to 120 ) \\
\hline Women, 0 to 64 & 131 & (65 to 198$)$ & 22 & 104 & (60 to 147$)$ & 39 & 112 & (54 to 171 ) & 20 & 0.39 & 0.53 & 111 & (72 to 151$)$ \\
\hline \multicolumn{14}{|l|}{ Lung cancer: } \\
\hline Men, all ages & 104 & (85 to 123 ) & 161 & 97 & (83 to 112 ) & 320 & 103 & (84 to 121 ) & 172 & $<0.01$ & 0.99 & 100 & (88 to 113 ) \\
\hline Women, all ages & 173 & (127 to 218 ) & 89 & 111 & (85 to 137$)$ & 131 & 118 & (84 to 151 ) & 68 & 6.10 & 0.01 & 126 & (102 to 151$)$ \\
\hline Men, 0 to 64 & 125 & (91 to 160$)$ & 72 & 117 & (91 to 143 ) & 152 & 116 & (84 to 148 ) & 73 & 0.15 & 0.69 & 119 & (96 to 142 ) \\
\hline Women, 0 to 64 & 229 & (136 to 322$)$ & 41 & 153 & (98 to 208 ) & 66 & 151 & ( 83 to 220 ) & 29 & 3.28 & 0.07 & 169 & (116 to 222$)$ \\
\hline \multicolumn{14}{|l|}{ Respiratory disease: } \\
\hline Men, all ages & 112 & (91 to 132 ) & 163 & 113 & (96 to 130 ) & 326 & 101 & (82 to 119 ) & 161 & 0.55 & 0.46 & 109 & (95 to 123 ) \\
\hline Women, all ages & 108 & (85 to 131 ) & 116 & 107 & (89 to 125$)$ & 250 & 93 & (73 to 113 ) & 122 & 1.12 & 0.29 & 103 & (89 to 118 ) \\
\hline Men, 0 to 64 & 124 & (81 to 168$)$ & 46 & 112 & ( 81 to 144 ) & 93 & 100 & (64 to 137 ) & 41 & 0.93 & 0.33 & 111 & (84 to 138 ) \\
\hline Women, 0 to 64 & 156 & (89 to 223 ) & 32 & 130 & (84 to 175$)$ & 63 & 93 & (46 to 140 ) & 21 & 3.21 & 0.07 & 127 & (87 to 166$)$ \\
\hline \multicolumn{14}{|c|}{ Chronic obstructive airways disease: } \\
\hline Men, all ages & 114 & (75 to 152 ) & 48 & 120 & (88 to 153 ) & 104 & 142 & (99 to 185 ) & 66 & 1.94 & 0.16 & 124 & (95 to 152 ) \\
\hline Women, all ages & 67 & (30 to 103 ) & 16 & 110 & (72 to 148$)$ & 60 & 117 & (69 to 166$)$ & 34 & 3.64 & 0.06 & 103 & (72 to 134$)$ \\
\hline \multicolumn{14}{|l|}{ Circulatory disease: } \\
\hline Men, all ages & 100 & (90 to 109 ) & 538 & 97 & (89 to 104$)$ & 1055 & 95 & (86 to 105 ) & 562 & 0.26 & 0.61 & 97 & (91 to 104$)$ \\
\hline Women, all ages & 102 & (91 to 112 ) & 486 & 85 & (78 to 93 ) & 874 & 91 & (81 to 100$)$ & 512 & 3.34 & 0.07 & 91 & (84 to 97$)$ \\
\hline Men, 0 to 64 & 101 & (84 to 118 ) & 183 & 109 & (95 to 123 ) & 428 & 98 & (82 to 115 ) & 197 & 0.06 & 0.81 & 104 & (93 to 116 ) \\
\hline Women, 0 to 64 & 108 & (81 to 135$)$ & 86 & 109 & (89 to 129$)$ & 206 & 108 & (82 to 133 ) & 93 & $<0.01$ & 0.96 & 109 & (91 to 126$)$ \\
\hline
\end{tabular}

${ }^{\star}$ Logistic regression for a trend in the proportion dying in zones LA, LB, and LC taking into account sex and 5 year age group.

zones, which together had higher rate ratios than zone S (but the 95\% CIs included 100).

There were no clear cut patterns for circulatory disease in line with the study hypothesis.

Analysis based on the 15 community survey areas; that based on dividing the 27 Teesside areas into five zones; and analysis for three different periods (1981-4, 1985-7, and 1988-91) partially supported, but did not alter, this picture. ${ }^{8}$

\section{Discussion}

Investigation of concern about the health effects of local industrial pollution is one of the more difficult applications of epidemiology to public health. The technical problems are formidable, particularly estimating exposures and reaching judgements on cause and effect, ${ }^{18}{ }^{19}$ but the need to undertake and interpret a study in the public eye poses additional challenges. The study of populations concerned about the health effects of industrial pollution makes interpretation of self reported data difficult, especially when the health effects are subtle. ${ }^{20-22}$

Failure to unearth causal associations may harm the public health and weaken the case for environmental improvement and compensation. Interpreting mere association as causation may undermine the standing of industry, and damage the economic and health status of the community. In a Canadian city with petrochemical industry a pseudoepidemic of cancer arose from an error in the denominator, and led to a drop in property prices, public anxiety, and a lasting reputation as a cancer city. ${ }^{23}$

The present study was done amidst simmering controversy and adversarial dynamism, common underlying factors in studies of this kind which hinder resolution of conflict. ${ }^{19}$ The populations involved were at the extremes of deprivation in the United Kingdom, bringing the additional issues of inequalities of health to the fore. Our data collection was purposely comprehensive in scope, with a strong emphasis on both health data and social and economic information. The analysis of data in several ways was deliberate, to avoid missing any important health effects. This follows our strategy developed in examining the impact of pollution from a coking works ${ }^{15}$ and a wallpaper factory. ${ }^{24}$ The strategy of analysing data in several ways may be criticised on statistical grounds, but the recent reanalysis and reinterpretation of the data pertaining to the Three Mile Island nuclear reactor accident, which has given new conclusions, ${ }^{25}$ and controversy, ${ }^{26-30}$ is 
a reminder that there is scientific merit in comprehensive analysis, and an open and diverse approach to interpretation, which includes the perception of the affected community. ${ }^{19}$ Our statement of initial hypotheses, with a prediction of health gradients across the Teesside zones and between Teesside and Sunderland areas, was our principal guide to interpreting the many associations which are inevitably detected when large data sets are subjected to comprehensive analysis.

Severe air pollution undoubtedly affects health, which may be shown even years after the exposure as in the case of the gas leak in the City of Bhopal, ${ }^{31}$ but there is controversy on the health impact of low or variable levels of air pollution..$^{32-36}$ Studies on the local health impact of air pollution from industry do not yet provide generalisable principles, possibly because the effects, if any, are dependent on local context. Morbidity has been studied among several communities including those living close to coal fuelled power plants, ${ }^{37}$ gas refineries, ${ }^{38}$ pulp mills, ${ }^{39}$ iron foundries, ${ }^{40}$ petrochemical industries, ${ }^{41}$ power stations, ${ }^{42}$ a coking works ${ }^{15}$ a wallpaper factory ${ }^{24}$ chemical dumping sites, ${ }^{43}$ and a cement works. ${ }^{44}$ Some studies have shown a health impact, others have not.

Studies of mortality have also been done. For example, a study of communities living close to steel foundries in central Scotland concluded that the high risk of lung cancer was causally linked to industrial air pollution. ${ }^{45}$ Fear of a raised incidence of laryngeal cancer in people living near oil and solvent incinerators was not verified. ${ }^{46}$ Studies of mortality relating to radiation hazards have been a source of controversy and methodological difficulty. ${ }^{25-30}$ Relatively few studies have simultaneously studied morbidity and mortality.

Of the methodological questions that determine the value of this study (and others like it) two are outstanding: was the population chosen as the focus of the study (in zone A) the right one, and were the populations in the zones sufficiently alike to sustain comparisons of the kind made?

\section{CHOICE AND CHARACTERISTICS OF AREAS AND}

ZONES

Proximity of residence to industry as a proxy for exposure is the basis of many studies of industrial impact on local health. ${ }^{47}$ The populations of zone A were the focus of the study because of their proximity to major industry, their economic hardship, their previously demonstrated high mortality and the hypothesis that at least part of their poor health was attributable to industrial pollution..$^{1-5}$

Teesside and Sunderland have been similar economically for many decades. ${ }^{48}$ Comparison between the 1981 and 1991 censuses showed social and economic similarity of the areas studied. ${ }^{8}$ The 1993 community survey confirmed that the zones were well matched economically and in lifestyle indicators including smoking. Similar proportions of men had at least 1 year's experience of working in heavy industries. Variations in specific male occupational histories, however, reflect the different industries of the two conurbations with steel and chemicals dominant in Teesside and deep coal mining in Sunderland. Differences in the socioeconomic indicators of access to a car or van and living in rented accommodation are a reflection of different historical traditions of public housing and public transport provision between Teesside and Sunderland. Within Teesside the three study zones were highly comparable on social and economic factors, both historically and currently, but were different in their proximity to petrochemical and steel industries.

Modelled data confirmed indications from monitored data that there is spatial variation in exposure to industrial air pollutants across Teesside. ${ }^{814}$ We have no detailed retrospective exposure information but evidence from the historical land use survey ${ }^{8}$ shows that our zone A has been close to industry throughout this century, and monitoring data on insoluble solids, ferric oxide, smoke, and $\mathrm{SO}_{2}{ }^{9-13}$ confirm that pollution in the Teesside areas closest to industry has been higher than in areas further away. Studies by Wicken and Buck ${ }^{2}$ and Dean et $a l^{3}$ showed relatively high levels of $\mathrm{SO}_{2}$ and smoke in the Eston area, which overlaps with our zone A. The evidence supports our assumption that exposure to industrial pollution has varied with proximity to industry.

WERE THERE DIFFERENCES IN HEALTH BETWEEN THE POPULATIONS STUDIED?

Patterns of illness or disability, as measured in the community survey and general practice records study showed some differences across the zones. Particularly for children, respiratory symptoms were higher in the Teesside zones combined than in zone $S$. For no measure of morbidity was there a convincing gradient across the three Teesside zones $(A>B>C)$ and between Teesside and Sunderland $(\mathrm{ABC}>\mathrm{S})$ as hypothesised. The view that the high prevalence of asthma in Teesside might be linked to local industrial emissions was not supported. Our data are mainly on the prevalence of diseases with extremely limited detail about the possible exacerbation of diseases by industrial pollution (an area for future research). Holtby et al showed that those living within $1 \mathrm{~km}$ of the major industries had a higher prevalence of otitis media with effusion but in a logistic regression analysis incorporating distance from industry and an economic disadvantage score, no association was apparent, leading the authors to an equivocal conclusion. ${ }^{68}$ The analyses of daily air pollution and general practice consultation rates indicated that local variations in air quality were not sufficient to create clinically important and measurable effects on consultation behaviour.

The above findings seem surprising. On the basis of previous research, and testimony from medical personnel and local residents, ${ }^{1-5}$ the expectation was that living close to industry would augment the health problems of people living in neighbourhoods where material hardship is widespread and longstanding. Some gradients in ill health might have been anticipated on the basis of artefact alone, for 
example, awareness bias. ${ }^{20} 21$ These were not found. Some studies have linked particulate air pollution with respiratory diseases ${ }^{49}$ and acute asthma. ${ }^{50}$ Others, however, failed to find a relation between increased prevalence of asthma and higher concentrations of pollution as recently summarised by the Committee on the Medical Effects of Air Pollution. ${ }^{51}$

The mortality findings were complex. Some differences between Teesside zones combined and the Sunderland zone were found for all cause mortality (0-64 year age group), all cancers excluding lung, and particularly relative to lung cancer and respiratory mortality in women. Mortality ratios for lung cancer in women were extremely high in the Teesside zones, and highest in the zone closest to industry. In several analyses carried out at various levels of spatial and temporal aggregation, ${ }^{78}$ only lung cancer deaths among women were consistently highest in the zone closest to industry and in the combined Teesside zones when compared with Sunderland. The findings for lung cancer in women, and to a lesser extent, respiratory mortality, particularly in women 0-64 years old, agreed with the study hypothesis. There were no important differences between women in the study zones in smoking, occupation, and poverty levels. The questions raised by our findings on the different lung cancer patterns found in women and men and the possibility of subtle differences in smoking patterns not apparent in our and others' cross sectional data, ${ }^{23}$ are discussed in detail elsewhere. ${ }^{78}$ We judged that the evidence pointed to a role for industrial air pollution in the higher levels of lung cancer in women living close to industry in Teesside. ${ }^{7}$

In conclusion, living close to the constellation of petrochemical and steel industries does not have clear effects on morbidity or on most causes of death. For lung cancer, and to a lesser extent respiratory mortality, particularly in women, the evidence points to an effect. The reasons for the different patterns in men and women, in those $<65$ years and at all ages, and the precise causes and future course of lung cancer mortality in women in Teesside, warrant further research.

Grants to enable this research to take place were received from the Middlesbrough Borough Council (City Challenge), South Tees Health Authority and Tees Health, Cleveland Family Health Services Authority, Cleveland County Council, NorthHealth Services Authority, Cleveland County Council, North-
ern and Yorkshire Regional Health Authority. For help, support, expertise and advice we thank: Dr H R Gribbin, Dr I Guy, Dr R expertise and advice we thank: Dr H R Gribbin, Dr I Guy, Dr R
Harrison, Mr J R Hindmarsh, Mr P Loker, Dr S Ramaiah, Dr I Harrison, Mr J R Hindmarsh, Mr P Loker, Dr S Ramaiah, Dr I
Ruffett, John Mann, David Thompson, Les Milne, Colin Mills, Paul Reynolds, Bill Carruthers, John Stevenson, Jim Waldron, Paul Reynolds, Bill Carruthers, John Stevenson, Jim Waldron,
Angus McNay, Marjorie Renwick, Jill Rollings, Philip Baldwin, Colin Waine, Susan Mills, Alastair Beattie, Dick Derwent, Simon Raybould, Martin Charlton, David Newrick, Martin Strange, Hazel Keeble, Jane Halpin, Fred Nimmo, Alison Watson, Drs Joshi and Acquilla, Ann Rooke, Patricia McCluskey, Debbie Nash, Simon Kingham, Alan Bush, Alistair Hay, Raymond Agius, Finton Hurley, members of the Industry/ Researchers Group, AEA Technology (formally Warren Spring Laboratory), Carolyn McGregor, Dawn Winpenny, Louise Walker, Lorna Hutchinson, and Carole Frazer. Finally, we thank an anonymous referee for detailed comments which greatly influenced the presentation of this paper. The following were members of the Teesside Environmental Epidemiology Group: Professor Raj Bhopal (chairman), Professor Peter Blain, Ms Jo Denn, Mr Jeff Duffield, Dr Christine Dunn, Dr John Edwards, Denn, Mr Jeff Duffield, Dr Christine Dunn, Dr John Edwards,
Mr Christopher Foy, Mrs Cathrine Hall, Dr Erasmus Harland, Dr Ian Holtby, Dr Jim Longstaff, Dr Suzanne Moffatt, Dr Peter Dr Ian Holtby, Dr Jim Longstaff, Dr Suzanne Moffatt, Dr Peter
Phillimore, Dr Tanja Pless-Mulloli, Ms Jacqui Tate, Dr Anthony Luke, Ms Lesley Sharpe, Mr David Sutherland.
1 Medical Officer of Health. Annual report. Teesside: Eston Urban District, 1921.

2 Wicken AJ, Buck SF. Report on a study of environmental factors associated with lung cancer and bronchitis mortality in areas of north east England. London: Tobacco Research Council Report, 1964.

3 Dean G, Lee PN, Todd GF, et al. Report on a second retrospective mortality study in north-east England. Part II: changes in lung cancer and bronchitis mortality and in other relevant factors occurring in areas of north east England 1963-72. London: Tobacco Research Council Report; 1977.

4 Phillimore P, Morris D. Discrepant legacies: premature mortality in two industrial towns. Soc Sci Med 1991;33:139-52.

5 Gavin H. A survey investigation of perceptions of environGavin H. A survey investigation of perceptions of environ-
mental issues in Middlesbrough. Clean Air 1996;26:10-15.

6 Holtby I, Elliott K, Kumar U. Is there a relationship between proximity to industry and the occurrence of otitis media with effusion in school entrant children? Public Health 1997;111:89-91.

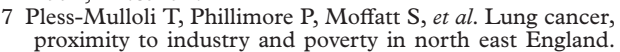
Environ Health Perspect 1998;106:189-96.

8 TEES (Teesside Environmental Epidemiology Study) Group. Health, illness and the environment in Teesside and Sunderland. Newcastle upon Tyne, UK: University of Newcastle; 1995.

9 Medical Officer of Health. Annual report. Teesside: Borough of Stockton, 1964

10 Medical Officer of Health. Annual report. Teesside: Borough of Stockton, 1967

11 Teesside County Borough Council Health Department. The Health of Teesside During 1968. Teesside, UK: Teesside County Borough Council Health Department, 1968.

12 Cleveland County Borough Council. Report for the committee for the co-ordination of air pollution and noise. Analysis of air Cleveland County Borough Council, 1982.

13 Cleveland County Borough Council. Report for the committee for the co-ordination of air pollution and noise. Analysis of air porthe co-ordination of air pollution and noise. Analysis of air pleveland County Borough Council, 1975.

14 Department of the Environment. The United Kingdom national air quality strategy. London: Department of the Environment, 1996.

15 Bhopal RS, Phillimore P, Moffatt S, et al. Is living near a coking works harmful to health? $\mathcal{f}$ Epidemiol Community Health 1994;48:237-47.

16 Williams ES, Scott CM, Scott SH. Using mortality data to describe geographical variations in health status at sub-district level. Public Health 1995;109:67-73.

17 Office of Population Censuses and Surveys. How complete was the 1991 Census? Popul Trends 1993;71:22-5.

18 Lippman M, Lioy PJ. Critical issues in air pollution epidemiology. Environ Health Perspect 1985;62:243-58.

19 Cole DC, Tarasuk V, Frank JW, et al. Research responses to outbreaks of concern about local environments. Arch Environ Health 1996;51:352-8.

20 Malmberg P, Coking to death? Lancet 1994:344:632.

21 Mayon-White RT, Commentary: assessing the effects of environmental pollution when people know that they have been exposed. BMF 1997;314:343.

22 Moffatt S, Phillimore P, Bhopal R, et al. If this is what it's doing to our washing, what is it doing to our lungs? Industrial pollution and public understanding in north-east England. Soc Sci Med 1995;41:883-91.

23 Guidotti TL, Abercrombie S. Voices of leadership in a community under stress: personal observations by officials on an epidemiologic mistake. $\mathcal{F}$ Public Health Med 1994;16: 381-8.

24 Kingham SP, Aquilla SD, Dunn CE, et al. Health in the vicinity of industry in Bishop Auckland. Newcastle upon Tyne, UK. University of Newcastle; 1995

25 Wing S, Richardson D, Armstrong D, et al. A re-evaluation of cancer incidence near the Three Mile Island nuclear plant: the collision of evidence and assumptions. Environ Health Perspec 1997;105:52-7.

26 Dieter MP, Open scientific debate for conflicts in science. Environ Health Perspect 1997;105:10.

27 Hatch M, Susser M, Beyea J. Comments on a re-evaluation of cancer incidence near the Three Mile Island nuclear plant. Environ Health Perspect 1997;105:12.

28 Wing S, Richardson D, Armstrong D. Reply to comments on a re-evaluation of cancer incidence near the Three Mile

29 Susser S. Consequences of the 1979 Three Mile Island accident continued: further comment. Environ Health Perspect 1997;105:2-3.

30 Wing S, Richardson D, Armstrong D. Response: science, public health and objectivity: research into the accident at Three Mile Island. Environ Health Perspect 1997;105:3-5.

31 Cullinan P, Acquilla S, Ramana Dhara V. Respiratory morbidity 10 years after the Union Carbide gas leak at Bhopal: a cross sectional survey. BMf 1997;314:338-42.

32 Dockery DW, Pope CAI, Xu X, et al. An association between air pollution and mortality in six US cities. $N$ Engl f Med 1993;329:1753-9.

33 Schwartz J. Air pollution and daily mortality: a review and meta analysis. Environ Res 1994;64:36-52.

34 Touloumi G, Pocock SJ, Katsouyanni K, et al. Short-term effects of air pollution on daily mortality in Athens: a timeeffects of air pollution on daily mortality in Athen
series analysis. Int f Epidemiol 1994;23:957-67.

35 Seaton A, MacNee W, Donaldson K, et al. Particulate air pollution and acute health effects. Lancet 1995;345:176-8. 
36 Moolgavkar SH, Luebeck EG, Hall TA, et al. Air pollution and daily mortality in Philadelphia. Epidemiology 1995;6: and daily

37 Cohen AA, Bromberg S, Buechley RW, et al. Asthma and air pollution from a coal-fuelled power plant. Am f Public Health 1972;62:1181-8.

38 Dales RES, Suissa WO, Schechter S, et al. Respiratory health of a population living downwind from natural gas refineries. Am Rev Respir Dis 1989;139:595-600.

39 Jaakola JJ, Vilkka V, Marttila O, et al. The South Karelia air pollution study: the effects of malodorous sulfur compounds from pulp mills on respiratory and other symptoms. Am Rev Respir Dis 1990;142:1344-50.

40 Symington $\mathrm{P}$, Coggon D, Holgate S. Respiratory symptoms in children at schools near a foundry. $\mathrm{Br} F$ Ind Med 1991;48:588-91.

41 Ware JH, Spengler JD, Neas LM, et al. Respiratory and irritant health effects of ambient volatile organic compounds: the Kanawha County health study. Am f Epidemio 1993;137:1287-301.

42 Halliday J, Henry R, Hankin RG, et al. Increased wheeze but not bronchial hyper-reactivity near power stations. F Epidemiol Community Health 1993:47:282-6.

43 Dayal H, Gupta S, Trieff N, et al. Sympton clusters in a community with chronic exposure to chemicals in two superfund sites. Arch Environ Health 1995;50:108-11.
44 Ginns S E, Gatrell A C. Respiratory health effects of industrial air pollution: a study in east Lancashire, UK. $\mathcal{F}$ Epidetrial air pollution: a study in east Lanca
miol Community Health 1996;50:631-5.

45 Lloyd OL, Williams FLR, Gailey FA. Is the Armadale epidemic over? Air pollution and mortality from lung cancer and other diseases, 1961-82. Br F Ind Med 1985;42: 815-23.

46 Elliott P, Hills M, Beresford J, et al. Incidence of cancers of the larynx and lung near incinerators of waste solvents and oils in Great Britain. Lancet 1992;339:854-8.

47 Elliott P, Cuzick J, English D, et al. Geographical and environmental epidemiology: methods for small-area studies. Oxford: mental epidemiology: methods for
Oxford University Press, 1994.

48 Beynon H, Hudson R, Sadler D. A place called Teesside: a locality in a global economy. Edinburgh: University Press; 1994.

49 Pope CA, Dockery DW. Acute health effects of PM10 pollution on symptomatic and asymptomatic children. $\mathrm{Am}$ Rev Respir Dis 1992;145:1123-8.

50 Walters S, Griffiths RK, Ayres JG. Temporal association between hospital admissions for asthma in Birmingham between hospital admissions for asthma in Birmingham 1994;49:133-44.

51 Committee on the Medical Effects of Air Pollutants. Asthma and outdoor air pollution. London: HMSO, 1995.

\section{Vancouver style}

All manuscripts submitted to Occup Environ Med should conform to the uniform requirements for manuscripts submitted to biomedical journals (known as the Vancouver style.)

Occup Environ Med, together with many other international biomedical journals, has agreed to accept articles prepared in accordance with the Vancouver style. The style (described in full in the $\mathcal{F} A M A[1]$ ) is intended to standardise requirements for authors, and is the same as in this issue.

References should be numbered consecutively in the order in which they are first mentioned in the text by Arabic numerals on the line in square brackets on each occasion the reference is cited (Manson[1] confirmed other reports[2][3][4][5]). In future references to papers submitted to Occup Environ Med should include: the names of all authors if there are three or less or, if there are more, the first three followed by et al; the title of journal articles or book chapters; the titles of journals abbreviated according to the style of Index Medicus; and the first and final page numbers of the article or chapter. Titles not in Index Medicus should be given in full.

Examples of common forms of references are:

1 International Committee of Medical Journal Editors. Uniform requirements for manuscripts submitted to biomed journals. $7 A M A$ 1993;269:2282-6.

2 Soter NA, Wasserman SI, Austen KF. Cold urticaria: release into the circulation of histmaine and eosinophil chemotactic factor of anaphylaxis during cold challenge. N Engl f M Med 1976;294:687-90.

3 Weinstein L, Swartz MN. Pathogenic properties of invading micro-organisms. In: Sodeman WA Jr, Sodeman WA, eds. Pathologic physiology, mechanisms of disease. Philadelphia: W B Saunders, 1974:457-72. 